\title{
Determination of Locus of Control, HR Competence and Information Technology Towards Distro Performance in Increasing MSME Income
}

\author{
Fivi Rahmatus Sofiyah ${ }^{1 *}$, Yeti Meliany Lubis ${ }^{2}$, Ami Dilham ${ }^{3}$ \\ ${ }^{1}$ Universitas Sumatera Utara \\ ${ }^{2}$ Universitas Sumatera Utara \\ ${ }^{3}$ Universitas Sumatera Utara \\ Email:fivi.rahmatus@usu.ac.id
}

\begin{abstract}
The purpose of this study is to find out how the determination of locus of control, HR competence and information technology on distribution performance in increasing MSME income. The population in this study were all distributions. Determination of the sample in this study using the Slovin formula with purposive sampling, which obtained as many as 200 samples. The data collection method used is a survey method by distributing questionnaires and documentation. The number of returned questionnaires was 200 questionnaires. The data analysis method in this research is path analysis with smartpls. Based on the results of the study, Locus of control affect the performance in increasing the income of MSMEs, HR competence affects the performance in increasing the income of MSMEs, Information technology affects the performance in increasing the income of MSMEs.
\end{abstract}

Keywords: Locus of control, HR Competence, Information Technology, Performance, Income, MSME.

\section{INTRODUCTION}

Micro, Small and Medium Enterprises (MSMEs) are undeniably the backbone of the national economy. Entrepreneurship requires a good work team, creativity, innovation, good leadership, potential market opportunities, sufficient capital, good financial arrangements, and much more. According to [1] "every business that is built will definitely face challenges and obstacles". In a study by A. McKinsky \& Company in [2], it is proven that there are ten main business obstacles in business growth and development, including nonsales, high initial costs, lack of HR skills, lack of innovation to produce products that new, difficult access to funding, insufficient profits, lack of confidence, high cost suppliers, bureaucratic barriers, and high loan interest rates.

In the sector of improving human resources, it is hoped that information technology can create and improve the quality of human resources. Information technology is one of the most vital facilities in today's era for improving human resources. In the business or economic sector, especially in the field of micro, small and medium enterprises, technology is a mandatory thing that must be understood and mastered in order to be able to compete in the current era. Technology is a knowledge that aims to create tools for processing and extracting objects. The term of "technology" has been widely known and everyone has a way of their own to understand the meaning of technology. Technology is used to solve various problems in human life. In addition, technology is also used as a tool to expand human capabilities[3]. Meanwhile, what is meant by information is often equated with the meaning of data. Data is something that has not been processed and cannot be used as a strong basis for making a decision [4].

Human Resources (HR) is one of the important elements in the organization. SDM is a major pillar of an organization compared with elements of the other, such as technology or money because the man himself who can control these elements [5]. Competence is a key factor to determine someone in producing excellent performance [6]. Competency analysis is mostly devoted to career development and the level of competence is needed to determine the effectiveness of the expected level of performance [7]. HR competence is the ability of individuals within an organization/institution, or system to carry out their duties or authorities in achieving success efficiently and effectively [8]. Competence relates to the abilities that each individual must have in order to do his job well. Competence is a person's ability, this quality is a combination of expertise ( Skill) and knowledge ( knowledge) ability ( ability) to carry out work into individual characteristics to achieve maximum performance [9]; [10]; [11]. 
One of the important elements of individual performance contained within a person, namely Locus of control [12]. A person's perception of an achievement when acting in all activities in his life is called Locus of control [13]. Locus of control is control over an individual's work and belief in self-[14]. According to [15] there are two elements of locus of control, namely internal and external. Internal locus of control is if a person believes that an event is always under his control, always plays a role, and is responsible for decisionmaking actions. External locus of control is if a person believes that an event in his life is beyond his control. In an entity the role of Locus of control is very important because in each individual there is different self-control [16].

\section{LITERATURE REVIEW}

\subsection{Locus of control}

Locus of control is a personality trait that explains the perception from which individuals determine the causes of events in life [17]. [18] stated locus of control is the nature of the personality of a person in the interpretation of successes and failures experienced derived from an internal factor or factors themselves externally. Locus of control is defined as a person's beliefs about how and where the event felt unpleasant or not, be the basis for action [19]. Locus of control is a way of viewing a person in response to an incident dating life. According [14] locus of contro shows how much belief someone about the relationship between actions undertaken with the result that is accepted. Locus of control related to someone working attitude and self-image has. [20] divide locus of control into two, namely: internal and external locus of control. [21] those who tend to have an external locus of control will feel that every event they experience in their life is out of their control, for example by chance, fate or luck and for people with a dominant internal locus of control will feel they have a role or power. in everything that happens in his life.

\subsection{HR Competence}

[22] concludes that competence is everything about knowledge, skills, abilities and other characteristics that cause a person holding a position to be able to carry out his roles and responsibilities and contribute to meeting the needs of the company's organization according to the level of position he holds [23] suggests that competence is defined as knowledge, skills and abilities controlled by someone who has become a part of him, so that he can perform cognitive, affective and psychomotor behaviors as well as possible. If competence is defined as knowledge, it can be interpreted as knowledge to understand the vision and mission at work, knowledge to implement organizational strategies to achieve proper and good work results, and understand how important discipline is in the organization so that all rules can run well.
The characteristics of competence according to [23] there are five aspects, namely:

1. Motives are something that a person consistently thinks so that he takes action.

2. Traits are traits that make people behave or how someone responds to something in a certain way.

3. Self Concept is a person's attitudes and values. Attitudes and values measured by the test to the respondent to determine how the value of an individual's what appeals to someone in doing something.

4. Knowledge is information that a person has for a particular field. Knowledge is a complex competency.

5. Skills is the ability to carry out a certain task both physically and mentally.

\subsection{Information Technology}

Information technology is a general term for any technology that helps humans to create, change, store, communicate and/or disseminate information [24]. Meanwhile, according to [25] states that information technology is a technology used to process data, including processing, obtaining, compiling, storing, and manipulating data in various ways to produce quality information, namely relevant, timely, used information. For personal, business and government purposes, information technology is strategic information for decision making. Meanwhile, according to [26], information technology consists of hardware and software that companies need to achieve their business goals.

\subsection{Performance}

Performance is a record of -the results obtained from the function - the function of a particular job or activity for a certain period. Here the meaning of performance is emphasized to the end result or (outcomes). The term performance originates from the word Job Performance or Actual Performance (Actual work achievement or achievement achieved by someone) while in The New Webster Dictionary it gives meaning to the word performance which concerns the problem of achievement, performance and task execution [27]. is a very decisive thing in the development of the company [28]. Performance refers to the efficiency with which a product can achieve its expected goals. Usually good performance is synonymous with better quality. Emphasis on efficient use of human resources used

Performance is strongly influenced by the ability, motivation, enthusiasm and expectations of each individual contained in a person, group and company. Performance emphasizes the efficiency of saving the use of available resources to achieve the 
desired goals. In other words, performance is the productivity of a person, group or company, performance is said to be good and successful if the goals desired by individuals, groups and companies can be achieved properly. [27]. The performance of a business or company is a set of results achieved and refers to the act of achieving and carrying out the requested work. Thus the performance of a business or company is essentially the productivity of the individuals in the company [27]

\subsection{Income}

Revenue is the result of all sales of goods or services, a commodity. Income can also be interpreted as income arising from the activities of a business. According to [29], it is stated that income is formulated as the result of multiplying the number of units sold with the price per unit.

\section{RESEARCH METHODS}

This research is an associative research which is used to examine the relationship between two or more variables. This research was conducted to see the performance of distributions in increasing the income of MSMEs. The dependent variable are Revenues SMEs $(\mathrm{Y})$, the performance of distribution $(\mathrm{Z})$. The independent variables of this research are locus of control (X1), HR Competence (X2) and Information Technology (X3). The population in this study is MSME Distro with a total of 200 people. The method used in determining the sample study using the technique of random sampling. Methods of data collection that is used is observation, interviews and questionnaires. The technique used to process and analyze the data is to use Partial Least Square (PLS).

\section{RESULT AND CONCLUSION}

\subsection{Result}

This study uses path analysis to evaluate the effect of Locus of control, HR Competence, Information Technology on Distribution Performance to Increase MSME Income. The value of R2 is used to measure the level of variation of changes in the independent variable to the dependent variable. The $\mathrm{R} 2$ value of this study can be seen in the following table :

Table 1. R Square Output

\begin{tabular}{|l|l|l|}
\hline & R Square & $\begin{array}{l}\text { R Square } \\
\text { Adjusted }\end{array}$ \\
\hline Performance & 0.698 & 0.694 \\
\hline Income & 0.923 & 0.921 \\
\hline
\end{tabular}

Based on Figure 4.15 above, it can be concluded as follows:
1. R Square for performance variables by $69,8 \%$, which means that it is included in kategor i Strong. while the remaining $30.2 \%$ is explained by other variables outside the research model.

2. The value of R Square for variable Revenue amounted to $92,3 \%$, which means that it is included in Boston egori Strong. while the remaining $7.7 \%$ is explained by other variables outside the research model

Table 2. R Square Output

\begin{tabular}{|l|l|l|}
\hline & $\begin{array}{l}\text { T Statistics } \\
(\mid \text { O/STDEV })\end{array}$ & $\begin{array}{l}\text { P } \\
\text { Values }\end{array}$ \\
\hline Locus of control -> Performance & 2,969 & 0.003 \\
\hline Locus of control -> Income & 7.042 & 0.000 \\
\hline HR Competency -> Performance & 3.573 & 0.000 \\
\hline HR Competence -> Income & 4.406 & 0.000 \\
\hline $\begin{array}{l}\text { Information technology -> } \\
\text { Performance }\end{array}$ & 2,359 & 0.019 \\
\hline $\begin{array}{l}\text { Information technology -> } \\
\text { Revenue }\end{array}$ & 7.581 & 0.000 \\
\hline Performance -> Revenue & 5.885 & 0.000 \\
\hline $\begin{array}{l}\text { Information technology -> } \\
\text { Performance -> Revenue }\end{array}$ & 2.115 & 0.035 \\
\hline $\begin{array}{l}\text { Locus of control -> Performance - } \\
>\text { Revenue }\end{array}$ & 2,723 & 0.007 \\
\hline $\begin{array}{l}\text { HR Competence -> Performance - } \\
>\text { Income }\end{array}$ & 3.088 & 0.002 \\
\hline
\end{tabular}

The following is a discussion of each hypothesis test based on the test results summarized in the Table 2 :

1. Effect of Locus of control on Performance Based on the table. 2 explains that the influence of locus of control of the performance $(\mathrm{p}=0,00<0.05) \mathrm{H} 0$ rejected $\mathrm{H} 1$ accepted, meaning there is positive and significant correlation between locus of control with performance .

A study conducted by [30] stated that a higher internal locus of control can encourage an increase in employee performance. In addition, in the research of Dl. [31], [18], [31] state that locus of control can affect the performance of employees. Failure in a job should be considered as an unstable thing, where we assume that the success achieved is the result of external factors and when experiencing failure internal factors are said to be the cause [32].

2. The Effect of Locus of Control on Income Based on the table. 2 illustrates that the influence of locus of control on income $(\mathrm{p}=0,00<0.05) \mathrm{H} 0$ rejected $\mathrm{H} 1$ accepted, meaning there is positive and significant correlation between locus of control with Revenue. In the research of [8] stated that locus of control has a positive effect on the quality of financial reports. In addition, the results of research found by [33] that there is a positive influence between locus of control and the performance of credit analysts. In contrast to the results of research from [34] that there is a negative influence between external locus of control and individual performance. 
3. The Influence of HR Competence on Performance Based on the table. 2 illustrates that the influence of HR Competency on the Performance ( $p=0,00$ $<0.05) \mathrm{H} 0$ rejected $\mathrm{H} 1$ accepted, meaning there is positive and significant correlation between HR Competency with Performance.

As already explained that there are several things contained in the performance. Among them are stated by [35] namely effectiveness and efficiency. Authority (Authority), Discipline and Initiative. Besides that, the components that make up competencies in [36] include knowledge, skills, selfconcept, self-characteristics and motives that have the potential to affect existing performance. These results can also be proven through previous research including by [37] regarding the influence of competence on employee performance quite a lot, but the author refers to research conducted on the effect of work competence on lecturer performance. The results of the study indicate that competence, which consists of: knowledge, skills and work experience has a significant influence on improving lecturer performance. While the most dominant variable affecting the performance of lecturers is knowledge.

4. The Influence of HR Competence on Income Based on the table. 2 illustrates that the influence of Competence HR to income ( $\mathrm{p}=0,00<0.05$ ) H0 rejected $\mathrm{H} 1$ accepted, meaning there is positive and significant correlation between HR Competency with Revenue.

This shows that, with good HR competence, knowledge and ability regarding matters relating to financial aspects will improve the ability to manage finances in the company is also getting better so that it will increase the financial capability of an MSME. They are not trusted to get a loan for several reasons, firstly, there is still a lack of knowledge and procedures in understanding the requirements to apply for a loan to a financial institution, secondly, they do not meet the requirements of the entrepreneur to apply for a loan to a financial institution. Both of these reasons, if seen, will come from the lack of competence of entrepreneurs regarding the ins and outs of applying for loans to financial institutions.

5. Effect of Information Technology on Performance Based on the table. 2 illustrates that the influence of Information Technology on the Performance $(\mathrm{p}=0$, $00<0.05) \mathrm{H} 0$ rejected $\mathrm{H} 1$ accepted, meaning there is positive and significant correlation between the Information Technology with Performance .

Thus it can be concluded that the mastery of information technology has a positive and significant effect on employee performance, where by providing empirical evidence that the mastery of information technology for employees which includes: the usefulness/benefits of IT, ease of use of IT, attitudes towards IT behavior, IT behavioral intentions, and behavior towards IT so that it can affect employee performance. So that it can be seen the performance of employees according to the SKI assessment at this company to get performance criteria that reach the target, above the target even extraordinary performance criteria as well as good competence even very good behavioral intentions are needed from each employee in mastering information technology so as to produce work quality, quantity work, punctuality and independence of each individual

In the performance criteria, in the implementation of work, if an employee makes a mistake, he will get a warning, on the other hand, if he does, he will get a reward. Employees carry out tasks in accordance with the limits of authority based on job descriptions, report work results according to actual conditions, carry out work with enthusiasm, a sense of responsibility, efficiently and effectively and independently. So the individual characteristics of employees as one of the factors that have relevance for the organization and is believed to be able to contribute to employee performance (Pio, et al 2015)

6. Effect of Information Technology on Revenue Based on the table. 2 illustrates that the influence of information technology on the Revenues ( $p=0,00$ $<0.05) \mathrm{H} 0$ rejected $\mathrm{H} 1$ accepted, meaning there is positive and significant correlation between the Information Technology by Revenue.

Thus, by utilizing developing modern technology, the increase will not be able to provide positive results for national economic growth. Information technology is helping to increase revenue SMEs is to market or promote wares in social media or by way of online sales on the other hand sellers can sell in his shop and can sell its goods online. Information Technology is the utilization of technology developments and internet-based applications provided by digital platform companies to market and sell service products with the expectation of a sustainable increase in operating income. This research is supported by (Hasanah, Kholifah, and Alamsyah 2020) who are related to this research, where technology both has a positive effect on the income of MSMEs in Purbalingga Regency. When utilizing information technology correctly, the income of MSMEs obtained will also increase. In addition, the use of technology for sales and marketing activities such as the use of social media can reach more people in a shorter time, and is cheaper and has a wider reach.

7. Effect of Performance on Revenue Based on the table. 2 illustrates that the influence of performance against revenue $(\mathrm{p}=0,01<0.05) \mathrm{H} 0$ rejected $\mathrm{H} 1$ accepted, meaning there is positive and significant correlation between performance with revenues.

The workforce can assist in the production process and serve consumers so that consumer demands can be met. If consumer demand can be met then income will also increase. This shows that the relationship between labor and income is positive, meaning that 
the increasing number of workers will increase productivity so as to increase the income of Batik Center SMEs in Pekalongan City. This study is in line with research conducted by Anjani (2017) where in this study the variable number of workers has an effect on income with a coefficient value of 0.762 . The results of the regression analysis from the partial test also show that the number of workers is a factor that has a significant effect on the income of shop business owners. coffee in Malang.

8. The Effect of Locus of Control on Revenue Through Performance Based on the table. 2 explains that the influence of Locus of control on Income through Performance $(\mathrm{p}=0.03<0.05)$ then $\mathrm{H} 0$ is rejected $\mathrm{H} 1$ is accepted, meaning that there is a positive and significant influence between Locus of control and income through Performance.

This study refers to the research found by [8] namely that locus of control has a significant positive effect on the quality of financial reports. In addition, in the research found by [33], namely the locus of control has a positive effect on the performance of credit analysts and in the research of [30] stated that the main influence of the level of locus of control on performance is significant, it means that the performance of the group of employees at the internal locus of control level is higher than the performance of the group at the external locus of control level. The LPD manager, namely the LPD management itself, is very important to have a locus of control because the locus of control has a role in employee performance motivation. The difference in locus of control that each individual has can describe different motivations and performances.

9. The Influence of HR Competence on Income through Performance Based on the table. 2 explains that the influence of HR Competence on Revenue through Performance $(\mathrm{p}=0.00<0.05)$ then $\mathrm{H} 0$ is rejected $\mathrm{H} 1$ is accepted, meaning that there is a positive and significant influence between HR Competence and Income through Performance

Competence is a key factor to determine someone in producing excellent performance [6]. Competency analysis is mostly devoted to career development and the level of competence is needed to determine the effectiveness of the expected level of performance [30]. The relationship between HR competence in accounting and the quality of financial reports refers to the results of research found by [8] and [30] which prove that there is a positive influence between human resource competence and the quality of financial reports. Then, in the research of [21] found that human resource competence has a positive influence on the quality of financial reports.

10. Effect of Information Technology on Revenue through Performance Based on the table. 2 illustrates that the influence of information technology on the Revenues through Performance $(\mathrm{p}=0,00<0.05) \mathrm{H} 0$ rejected $\mathrm{H} 1$ accepted, meaning there is positive and significant correlation between the Information Technology Revenue through Performance.

MSMEs need to take advantage of ICT to increase their competitiveness, considering that in this era of globalization, the arena of competition is increasingly competitive, and is global in nature. It also includes activities that support these market transactions, such as advertising, marketing, customer support, security, delivery, and payments. [26]. The type of E-Business used by airline service companies is B2C, namely Business to Customer. Ecommerce can be defined as the application and application of e-business (e-business) related to commercial transactions, such as: transfer of funds electronically, online marketing (online marketing), online transaction processing (Transaction Online), product promotion and others. -other. Respondents' responses to the company's performance variable (MSMEs) on the use of information technology showed that the company's performance in UMKM was significantly above the performance standard, meaning that the company's targeted performance could be achieved significantly above the company's performance standard because of the influence of the use of information technology, so that growth in production, sales, revenue, profit, return on investment, product development, marketing area, and human resources significantly increased above the company's performance standards.

\subsection{Conclusion}

1. Effect of Locus of control on Performance Based on the table. 2 illustrates that the influence of locus of control on the Performance $(\mathrm{p}=0,00$ $<0.05) \mathrm{H} 0$ rejected $\mathrm{H} 1$ accepted, meaning there is positive and significant correlation between locus of control with Performance.

2. The Effect of Locus of Control on Income Based on the table. 2 illustrates that the influence of locus of control on revenues $(p=0,00<0.05) \mathrm{H} 0$ rejected $\mathrm{H} 1$ accepted, meaning there is positive and significant correlation between locus of control by Revenue.

3. The Influence of HR Competence on Performance Based on the table. 2 illustrates that the influence of HR Competency on the Performance $(\mathrm{p}=0,00<0.05) \mathrm{H} 0$ rejected $\mathrm{H} 1$ accepted, meaning there is positive and significant correlation between HR Competency with Performance.

4. The Influence of HR Competence on Income Based on the table. 2 illustrates that the influence of Competence HR to income ( $\mathrm{p}=0,00<0.05)$ $\mathrm{H} 0$ rejected $\mathrm{H} 1$ accepted, meaning there is positive and significant correlation between HR Competency with Revenue.

5. Effect of Information Technology on Performance Based on the table. 2 illustrates that the influence of Information Technology on the Performance $(\mathrm{p}=0,00<0.05) \mathrm{H} 0$ rejected $\mathrm{H} 1$ 
accepted, meaning there is positive and significant correlation between the performance of Information Technology.

6. Effect of Information Technology on Revenue Based on the table. 2 illustrates that the influence of information technology on the Revenues ( $p=0$ , $00<0.05) \mathrm{H} 0$ rejected $\mathrm{H} 1$ accepted, meaning there is positive and significant correlation between the Information Technology Revenue.

7. Effect of Performance on Revenue Based on the table. 2 illustrates that the influence of performance against revenue $(\mathrm{p}=0,01<0.05)$ $\mathrm{H} 0$ rejected $\mathrm{H} 1$ accepted, meaning there is positive and significant correlation between the performance of Revenue.

8. The Effect of Locus of Control on Revenue Through Performance Based on the table. 2 explains that the influence of Locus of control on Revenue through Performance $(\mathrm{p}=0.03<0.05)$ then $\mathrm{H} 0$ is rejected $\mathrm{H} 1$ is accepted, meaning that there is a positive and significant influence between Locus of control and income through Performance

9. The Influence of HR Competence on Income through Performance Based on the table. 2 explains that the influence of HR Competence on Revenue through Performance $(\mathrm{p}=0.00<0.05)$ then $\mathrm{H} 0$ is rejected $\mathrm{H} 1$ is accepted, meaning that there is a positive and significant influence between HR Competence and Income through Performance

10. Effect of Information Technology on Revenue through Performance Based on the table. 2 illustrates that the influence of information technology on the Revenues through Performance ( $\mathrm{p}=0,00<0.05) \mathrm{H} 0$ rejected $\mathrm{H} 1$ accepted, meaning there is positive and significant correlation between the Revenue through Information Technology Performance.

\section{AUTHORS' CONTRIBUTIONS}

Fivi Rahmatus Sofiyah phenomenon and design research

Yeti Meliany Lubis Literature Review

Ami Dilham Analysis Statistic

\section{ACKNOWLEDGMENTS}

Research Institute in Universitas Sumatera Utara In Accordance With the Talenta Impementation Contract Number of the Universitas Sumatera Utara Fiscal Year 2021 Number: 6789/UN5.1.R/PPM/2021, 16 June 2021

\section{REFERENCES}

[1] Assagaf, Shannon Cecilia dan Lucky O.H. Dotulong.(2015). Pengaruh Disiplin, Motivasi dan Semangat Kerja terhadap Produktivitas Kerja Pegawai Dinas Pendapatan Daerah Kota Manado. Jurnal EMBA. Vol.3 No.2, Hal. 639-649.

[2] Pranashakti, Ipan. (2014). Strategi Bisnis : Memahami Tipe Pesaing Dalam Bisnis. (Online)

[3] Purwati, A. A., \& Hamzah, M. L. (2019). Total Service Quality Management And It's Impact On Customer Satisfaction And Loyalty Of Online Transportation In Indonesia. International Journal Of Scientific \& Technology Research, 8(11), 10661070

[4] Nozomi, I., \& Hamzah M. L. (2018). Aplikasi Pengolahan Data Surat Izin Usaha Angkutan Barang Pada Kantor Dinas Perhubungan Kabupaten Limapuluh. Journal of Information Technology and Computer Science (INTECOMS), 1(1), 110-118

[5] Anggiriawan, P. B., \& Sanjaya, Komang Adi Kurniawan Saputra, I. K. P. W. (2018). Prinsip Dualitas Dan Akuntansi Sumber Daya Manusia Dalam Keberhasilan Pengelolaan Dana Desa. Jurnal Analisa Akuntansi Dan Perpajakan, 2(September), $1-14$.

[6] Hidayah, N. \& Zarkasyi, W. (2017). The Effect of Human Resources Management Competency and the Role of Culture on Accrual Accounting Implementation Effectiveness and the Impact on Quality of Accounting Information. European Research Studies Journal Volume XX, Issue 4B 2017. Diakses dari http://search.proquest.com.

[7] Wardani, D. K., \& Andriyani, I. (2017). Pengaruh Kualitas Sumber Daya Manusia, Pemanfaatan Teknologi Informasi, Dan Sistem Pengendalian Intern Terhadap Keandalan Pelaporan Keuangan Pemerintahan Desa Di Kabupaten Klaten. Jurnal Akuntansi, 5(2), 88-98. https://doi.org/10.24964/ja.v5i2.270

[8] Karuniawan, W. M., Sujana, E., dan Yuniarta, G. A. (2017). Pengaruh Kompetensi Sumber Daya Manusia, Penerapan Teknologi Informasi, dan Locus Of Control Terhadap Kualitas Laporan Keuangan Pada Lembaga Pengkreditan Desa (LPD) di Kabupaten Buleleng Barat. E-Journal Akuntansi Universitas Pendidikan Ganesha, 8(2).

[9] Iqlima Azhar, Darwanis, S. A. (2013). Pengaruh Kualitas Aparatur Daerah, Regulasi, Dan Sistem Informasi Terhadap Manajemen Aset (Studi pada SKPD Pemerintah Kota Banda Aceh). Jurnal Akutannsi, 2(17), 15-26.

[10] Hariyani, D. S. (2016b). Analisis Pengaruh Kompetensi Aparatur Pemerintahan Desa Terhadap Penggunaan Teknologi Accounting Information System Pada Desa-Desa Di Kabupaten Madiun. 
Jurnal Akuntansi Dan Pendidikan, 5(2), 89-100. https://doi.org/10.25273/jap.v5i2.1191

[11] Akhmad Syarifudin. (2014). Pengaruh Kompetensi SDM dan Peran Audit Intern terhadap Kualitas Laporan Keuangan Pemerintah Daerah dengan Variabel Intervening Sistem Pengendalian Internal Pemerintah (studi empiris pada Pemkab Kebumen) Akhmad Syarifudin. Jurnal Fokus Bisnis, Volume 14, No 02, Desember 2014, 14(25), 26-44.

[12] Rotter, J.B. (1966), “Generalized expectancies for internal versus external control of reinforcement", Psychological Monographs, Vol. 80, pp. 1-28.

[13] Wibowo. 2010. Budaya Organisasi. Jakarta : PT. Raja Grafindo Persada

[14] Widyaninggrat, Anggi Ajeng.(2014). Pengaruh Efikasi Diri dan Lokus Kendali(Locus Of Control)Terhadap Prestasi Belajar Matematika.Jurnal Formatif.Universitas Indraprasta PGRI. 4(2):89-99

[15] Kreitner, Robert and Angelo Kinicki, 2001. Organizational Behavior. Fifth Edition. Irwin McGraw-Hill.

[16] Raditya, P.A. dan Wirajaya, I.G.A. (2018), "Pengaruh partisipasi anggaran dan penekanan anggaran pada senjangan anggaran dengan locus of control sebagai variabel pemoderasi”, Jurnal Penelitian Akuntansi.

[17] Malik, Muhamad Abdur Rahman, Arif N.Butt, Jin Nam Chom.(2015). Rewardsand Employee Creative Performance: Moderating Effects Of Creative SelfEfficacy, Reward Importance, and Locus Of Control.Journal of Organizational Behaviour.Wiley Online Library.36:59-74

[18] Gurendrawati, Etty. Yunika Murdayanti, and Anindya Gita Putri.(2014).TheImpact of Information Technology, Management Accounting SystemCharacteristics, and Locus of Control to the Managerial Performance in theTelecommunication Service Companies.Integrative Business \& EconomicsResearch.4(01):357-366

[19] Elena, Milka, Escalera-Chavez, Carlos, RojasKramer, Arturo COrdova-Rangel,Elena MorenoGarcia, and Arturo Garcia-Santillan.(2015). EmpiricalEvidence on Locus of Control among Owner andManager and Its Relationto Success Firms.Journal of Emerging Trends in Economics andManagement Sciences (JETEMS).6(3):177-184

[20] Robbins, Stephen P. dan Timothy A. Judge.(2008).Perilaku Organisasi,Jakarta:Salemba Empat

[21] Modise, Disebo and Patient Rambe.(2017). Internal and External Locus ofControl of Engineering Workforce in a Power Distribution
Untility:Impications forJob Performace.African Journal of Business and EcnomicResearch. 12 (2\&3):113-147.

[22] Sedarmayanti. 2016. Manajemen Sumber Daya Manusia Reformasi Birokrasi Dan Manajemen Pegawai Negeri Sipil. Bandung: PT. Refika Aditama.

[23] Sutrisno, Edy 2017, Manajemen Sumber Daya Manusia, Edisi Kedelapan, Prenada Media Group, Jakarta.

[24] Sawyer. L. B. 2007. Audit Internal Sawyer. Terjemahan Desi Adhariani Buku 1 Edisi 5. Jakarta: Salemba Empat.

[25] Rusdiana, A., dan M. Irfan. 2014. Sistem Informasi Manajemen. Bandung: CV. Pustaka Setia.

[26] Laudon, K. C, dan Jane P. Laudon. 2015. Sistem Informasi Manajemen. Jakarta: Penerbit Salemba Empat.

[27] Theo Suhardi. 2012. Entrepreneurship, UNPAD PRESS.

[28] Rahayu, Sri. 2010. Pengaruh Kinerja Keuangan Terhadap Nilai Perusahaan Dengan Pengungkapan Corporate Social Responbility dan Good Corporate Governance Sebagai Variabel Pemoderasi

[29] Mankiw, N. G. (2010). Pengantar Ekonomi Makro (Terjemahan). Erlangga.

[30] Wahyuni. Endang S. Taufeni Taufik, dan Vincen Ratnawati(2016).Pengaruh Budaya Organisasi,Locus of Control,Stres Kerja Terhadap Kinerja Aparat Pemerintah Daerah Dan Kepuasan Kerja Sebagai Variabel Intervening(Studi Empiris Pada Pemerintah Kabupaten Bengkalis).Jurnal Manajemen.20(02):189-206

[31] Appiah, F. and H. Addai.(2014).An Investigation Into The Causal RelationshipBetween Employees Locus Of Control And Contextual Performance.Journal Of Business and Behavioral Sciences.26(2):94-118

[32] Yi Li, Feng Wei, Shenggang Ren, Yang Di.(2014). Locus of Control,Psychological Empowerment and Intrinsic Motivation Relation toPerformance.Jounal of Managerial Psychology.30(4):422-438.

[33] Radityastuti, A. A. A. R., Astika, I. B. P., dan Wirakusuma, M. G. (2017). Pengaruh Locus of Control pada Kinerja Analis Kredit dengan Motivasi dan Lingkungan Kerja sebagai Pemoderasi. E-Jurnal Ekonomi dan Bisnis Universitas Udayana, 6(6), 2503-2528.

[34] Sudiartini, Ni Luh Yuli. (2018). Pengaruh Locus of Control dan Budaya Organisasi Berbasis Tri Hita Karana pada Kinerja Badan Pengawas. E-Jurnal Akuntansi Universitas Udayana, 22(1), 381-407. 
[35] Prawirosentono, S. 1999. Kebijakan Kinerja Karyawan. BPFE UGM, Yogyakarta.

[36] Abdullah, M, M. 2013. Manajemen Bisnis Syariah. Aswaja, Yogyakarta.

[37]Setiawati, T. 2009. Pengaruh Kompetensi Terhadap Kinerja Dosen (Studi Kasus di FPTK UPI). Journal Media Pendidikan, Gizi dan Kuliner. Vol. 1, No.1, hal.1-5. 